\title{
Antagonist and Partial Agonist Actions of d-Tubocurarine at Mammalian Muscle Acetylcholine Receptors
}

\author{
Joe Henry Steinbach and Qing Chen \\ Department of Anesthesiology, Washington University School of Medicine, St. Louis, Missouri 63110
}

\begin{abstract}
Currents were elicited by acetylcholine (ACh), by d-tubocurarine (dTC), and by mixtures of ACh and dTC, from stably transformed fibroblasts that express fetal or adult muscle nicotinic receptors. dTC acted as an antagonist of ACh for activation of adult-type receptors, whereas it acted as a weak partial agonist at fetal-type receptors. The channelblocking action of dTC was not apparent at the concentrations used. The partial agonism could explain previous observations that dTC is less effective at blocking the responses of fetal-type receptors than adult-type receptors. Binding of dTC to receptors was independently assayed by measuring the reduction of the initial rate of binding of iodinated $\alpha$-bungarotoxin. Binding of dTC to the two types of receptor was indistinguishable. The dose-effect relationship for the interaction of dTC and ACh at fetal receptors is consistent with the affinities of dTC measured in binding experiments.
\end{abstract}

[Key words: ACh receptor, curare, receptor activation, development, ligand binding, partial agonists, competitive antagonists]

$d$-Tubocurarine (dTC) has been used as a blocker of the skeletal muscle nicotinic acetylcholine receptor ( $\mathrm{AChR}$ ) for centuries by the indigenous peoples of South America, and for 40 years by anesthesiologists (Thomas, 1963). Most of its blocking action results from competitive inhibition of ACh binding to the AChR (Neubig and Cohen, 1979; Sine and Taylor, 1981), although it is clear that dTC also can act by inhibiting ion movement through the open channel (channel block; Colquhoun et al., 1979). Studies of the ability of dTC to inhibit membrane depolarization of muscle cells by ACh indicated that dTC blocked the AChR found at mature, innervated end-plates more effectively than it blocked the AChR found on denervated or immature muscle fibers (Jenkinson, 1960; Beranek and Vyskocil, 1967). Some biochemical studies of dTC binding also found a difference between fetal and adult AChR (Brockes and Hall, 1975), while others did not (Colquhoun and Rang, 1976; Kemp et al., 1980). Molecular cloning and expression experiments have demonstrated that the subunit composition of the $\mathrm{AChR}$ found at mature end-plates differs from that of the AChR on denervated

\footnotetext{
Received Apr. 18, 1994; revised June 8, 1994; accepted June 16, 1994.

We thank C. Kopta for advice, and G. Fletcher, C. Kopta, C. Lingle, and D. Maconochie for comments on the manuscript. This research was supported by Grants R01 NS22356 and P01 GM47969 to J.H.S.

Correspondence should be addressed to J. H. Steinbach, Department of Anesthesiology, Washington University School of Medicine, 660 South Euclid Avenue, St. Louis, MO 63110.

Copyright $(1995$ Society for Neuroscience $0270-6474 / 95 / 150230-11 \$ 05.00 / 0$
}

or fetal muscle: adult-type receptors have the subunit composition of $\alpha . \beta . \delta . \epsilon$ whereas fetal or denervated-type receptors have composition $\alpha . \beta . \delta . \gamma$ (Mishina et al., 1986). Recent results from biochemical studies of receptors expressed in nonmuscle cells demonstrate that ATC binds to the two types of AChR with indistinguishable affinity (Gu et al., 1990; Kopta and Steinbach, 1994), in contrast to the apparent difference in functional blockade.

In previous work we directly compared the results of two assays for $\mathrm{dTC}$ interaction with adult and fetal receptors stably expressed in fibroblasts: the occupancy of binding sites was determined from the decrease in the initial rate of $\alpha$-bungarotoxin binding and the functional consequences of binding were determined from the depression of whole-cell currents elicited by 400 nм ACh (Kopta and Steinbach, 1994). We found an apparent contradiction in the data. Occupancy determinations showed that the binding of dTC to fetal and adult receptors was indistinguishable. However, block of ACh-elicited currents by dTC differed for the two types of receptor, in that the halfblocking concentration of dTC for adult AChR was about sixfold lower than for fetal AChR. Hence, the two assays for dTC interaction gave different answers, depending on the receptor type studied. Because it is known that dTC can act as a weak activator of fetal-type AChR (Ziskind and Dennis, 1978; Takeda and Trautmann, 1984), we proposed that the lower degree of block might result from opening of channels of fetal-type receptors after the binding of one ACh and one dTC molecule (a heteroliganded AChR).

We have now tested the ability of mixtures of ACh and ATC to activate fetal-/and adult-type $\mathrm{AChR}$, and find that the results conform well to this hypothesized mechanism. The apparent affinities measured from the inhibition of BTX-binding can predict the observed actions on ACh-elicited currents.

\section{Materials and Methods}

Chemicals were obtained from Sigma Chemical (St. Louis, MO), unless otherwise specified.

Quail QT-6 fibroblasts were transfected with cDNAs coding for muscle AChR subunits and for resistance to the antibiotic geneticin, and stable clones were selected as described (Phillips et al., 1991; Kopta and Steinbach, 1994). Cells expressing fetal-type AChR (Q-F18) and adulttype AChR (Q-A33) were maintained in medium 199 (GIBCO, Grand Island, NY) containing 10\% tryptose phosphate broth (GIBCO), $5 \%$ fetal bovine serum (Hyclone, Logan, UT), 1\% DMSO, penicillin, streptomycin, and G-418 (GIBCO).

Populations of cells that express a high density of surface AChR were obtained by selective adhesion ("panning"; Barker et al., 1975). These selected cells will be described in more detail elsewhere (Chen and Steinbach, unpublished observations). Cells with high levels of surface AChR attached selectively to plastic Petri dishes coated with a monoclonal antibody that binds to an external epitope on the $\alpha$ subunit (mAb35; Tzartos et al., 1981). mAb-35 was purified from the supernatant of 
$100 \mathrm{nM} \mathrm{ACh}$

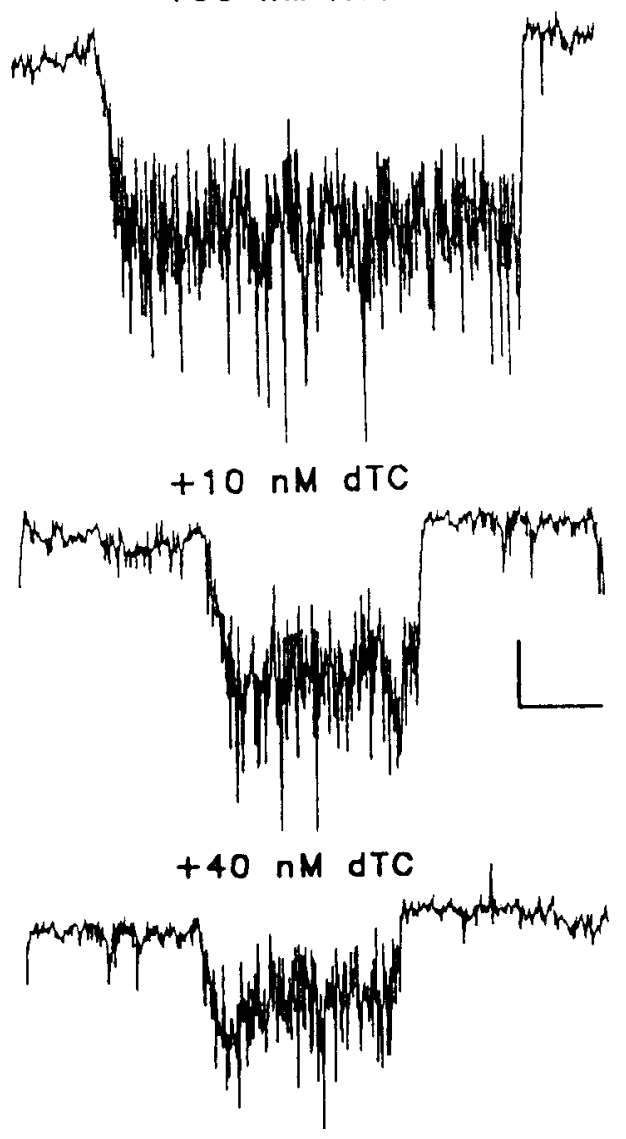

$1000 \mathrm{nM} \mathrm{ACh}$

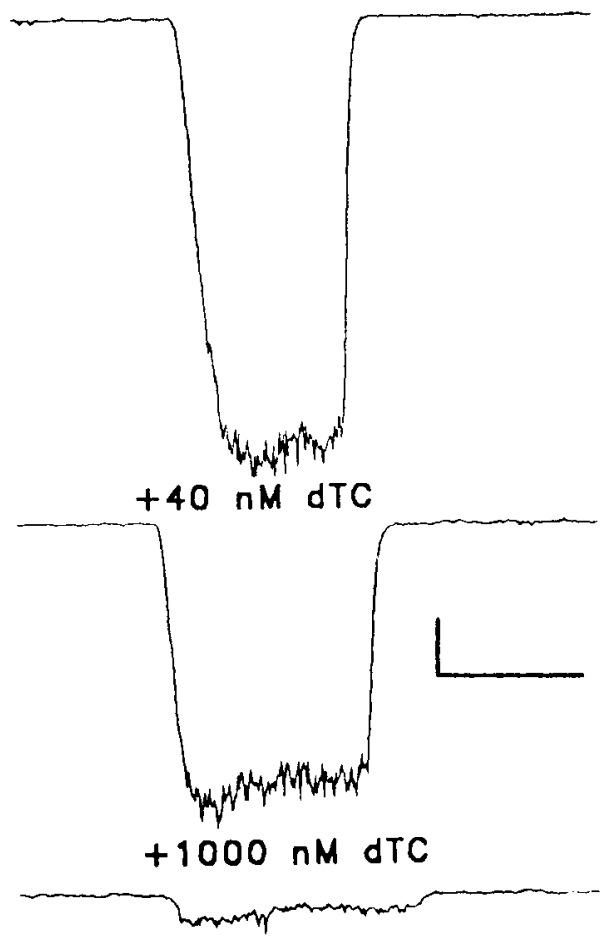

Figure 1. Currents elicited from Q-A33 cells by ACh are blocked by dTC: 100 nM ACh was applied to one cell (left column), either alone (top trace), with $10 \mathrm{nM}$ dTC (second trace), or with $40 \mathrm{~nm} \mathrm{dTC} \mathrm{(bottom} \mathrm{trace);} 1000 \mathrm{~nm}$ ACh was applied to a second cell (right column), alone (top trace), with $40 \mathrm{~nm} \mathrm{dTC} \mathrm{(second} \mathrm{trace),} \mathrm{or} \mathrm{with} 1000 \mathrm{~nm} \mathrm{dTC} \mathrm{(bottom} \mathrm{trace).} \mathrm{Note} \mathrm{that} \mathrm{dTC} \mathrm{blocked} \mathrm{at} \mathrm{all} \mathrm{combinations} \mathrm{of} \mathrm{ACh} \mathrm{and} \mathrm{dTC} \mathrm{concentration.}$ Data filtered at $20 \mathrm{~Hz}$ and sampled at $20 \mathrm{msec}$ intervals. Calibration: left column, $1 \mathrm{pA}, 2 \mathrm{sec}$; right column, $10 \mathrm{pA}, 2 \mathrm{sec}$.

cultures of the mAb hybridoma cells (American Type Culture Collection, Gaithersburg, MD) by ammonium sulfate precipitation and hydroxyapatite chromatography (Harlow and Lane, 1988). Cultures for studies of bungarotoxin binding had $2 \mathrm{~m} M$ sodium butyrate added to the growth medium $2 \mathrm{~d}$ prior to the assay. This treatment increased the number of AChR per cell and so enhanced the signal (Kopta and Steinbach, 1994). Some physiological cxperiments werc conducted on butyrate-treated cells. Butyrate had no effect on the action of dTC on currents elicited by ACh (data not shown; see Kopta and Steinbach, 1994) and so all the data have been pooled.

Binding of $\alpha$-bungarotoxin. Di-iodo- $\alpha$-bungarotoxin (I-BTX) was prepared by the iodine monochloride method (Vogel et al., 1972). The inhibition of the initial rate of I-BTX binding by dTC was determined as described (Kopta and Steinbach, 1994; see Sine and Taylor, 1981). The initial rate was estimated from the amount of I-BTX bound during a $15 \mathrm{~min}$ incubation with $10 \mathrm{nM}$ I-BTX at room temperature. Cultures were preincubated with a given concentration of dTC for $10 \mathrm{~min}$ before the addition of $10 \mathrm{~nm} \mathrm{I-BTX} \mathrm{plus} \mathrm{dTC.} \mathrm{Nonspecific} \mathrm{binding} \mathrm{was} \mathrm{de-}$ termined by the addition of $1 \mu \mathrm{M}$ unlabeled BTX to the $10 \mathrm{~nm}$ I-BTX. Binding was performed in a modified Earle's Balanced Salt Solution (EBSS; concentrations, in mM: $1.8 \mathrm{CaCl}_{2}, 0.8 \mathrm{MgSO}_{4}, 5.4 \mathrm{KCl}, 116$ $\mathrm{NaCl}, 1 \mathrm{NaH}_{2} \mathrm{PO}_{4}, 10$ HEPES, 120 glucose). The $\mathrm{pH}$ was adjusted to 7.3 and $0.2 \%$ fetal bovine serum was added. HEPES replaced the 26 $\mathrm{mm} \mathrm{NaHCO}$ in the original formulation.

The concentration dependence of the relative amount of I-BTX bound was analyzed by fitting the Hill function $\left(Y=\left(X / K_{h}\right)^{n} /\left(1+\left(X / K_{h}\right)^{n}\right)\right)$ and the relationship predicted for two binding sites of different affinity present in equal numbers $(Y=0.5(X / \mathrm{L} 1) /(1+(X / \mathrm{L} 1))+0.5(X / \mathrm{L} 2) /(1$ $+(X / \mathrm{L} 2)))$, where $Y$ is the fractional binding of I-BTX, $X$ is the dTC concentration, L1, L2 and $K_{h}$ are dissociation constants, and $n$ is the Hill coefficient.
Whole-cell recording. Standard techniques were used for whole-cell and excised patch recording (Hamill et al., 1981). Solutions were applied using a multiline perfusion apparatus (Konnerth et al., 1987). The solution exchange was relatively slow in these experiments (see Figs. 1, 2), taking about a second for $90 \%$ of a response to develop or dissipate. Hence, rapid block or desensitization would be missed. There is still debate over the rates for curare binding and dissociation at the AChbinding site. del Castillo and Katz (1957) suggested that dTC dissociated very slowly, but subsequent studies (Sheridan and Lester, 1977; Colquhoun and Sheridan, 1982; Le Dain et al., 1991) have provided indirect evidence that $\mathrm{dTC}$ has a dissociation rate constant of at least $1000 \mathrm{sec}^{-1}$, implying an association rate constant of $10^{9} \mathrm{M}^{-1} \mathrm{sec}^{-1}$. However, a recent study using rapid applications of dTC and ACh to patches of membrane containing mouse fetal-type AChR has suggested that the dissociation rate constant is about $10 \mathrm{sec}^{-1}$ and the association rate constant about $10^{8} \mathrm{M}^{-1} \mathrm{sec}^{-1}$ (Roper et al.l, 1993). Even with these slower rates, the interaction between dTC and ACh is likely to be at equilibrium during the relatively slow applications used.

The pipette (internal) solution contained (mM) $\mathrm{CsCl}, 140$; HEPES, $20 ; \mathrm{MgCl}_{2}, 1.0$; EGTA, 2.0; $\mathrm{pH}$ to 7.3 with $\mathrm{NaOH}$, with a final osmolarity of 285-295 mOsm. The bath contained (mM) NaCl, 140; HEPES, $10 ; \mathrm{CaCl}_{2}, 0.5$; glucose, $20 ; \mathrm{pH}$ to 7.3 with $\mathrm{NaOH}$, with a final osmolarity of $320-330$ mOsm. External solutions contained $300 \mathrm{~nm}$ atropine, to block muscarinic whole-cell responses.

Experiments were done at room temperature $\left(22-25^{\circ} \mathrm{C}\right)$. Data were recorded on digital tape, and replayed for subsequent analysis using a 386-based personal computer. Whole-cell responses were filtered at 20$300 \mathrm{~Hz}$ (low-pass Bessel; Frequency Devices, Haverhill, MA) and digitized at $50-1000 \mathrm{~Hz}$. Currents were then averaged over $25-100 \mathrm{msec}$ intervals and the peak response identified. The size of a response was taken as the mean of a 1-2 sec segment at the peak of the response, 
$40 \mathrm{nM} \mathrm{ACh}$
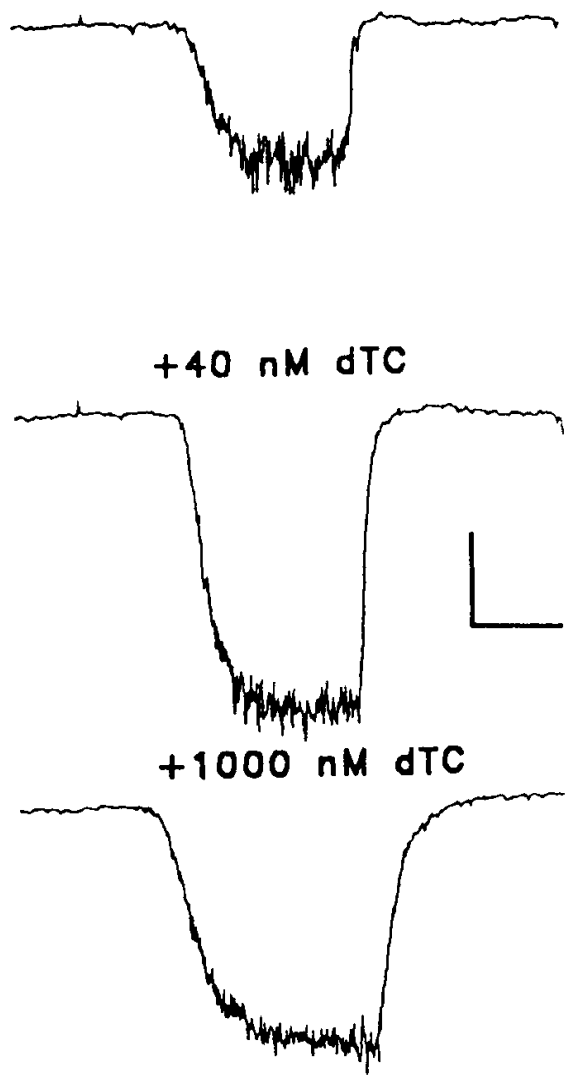

$1000 \cap M A C h$

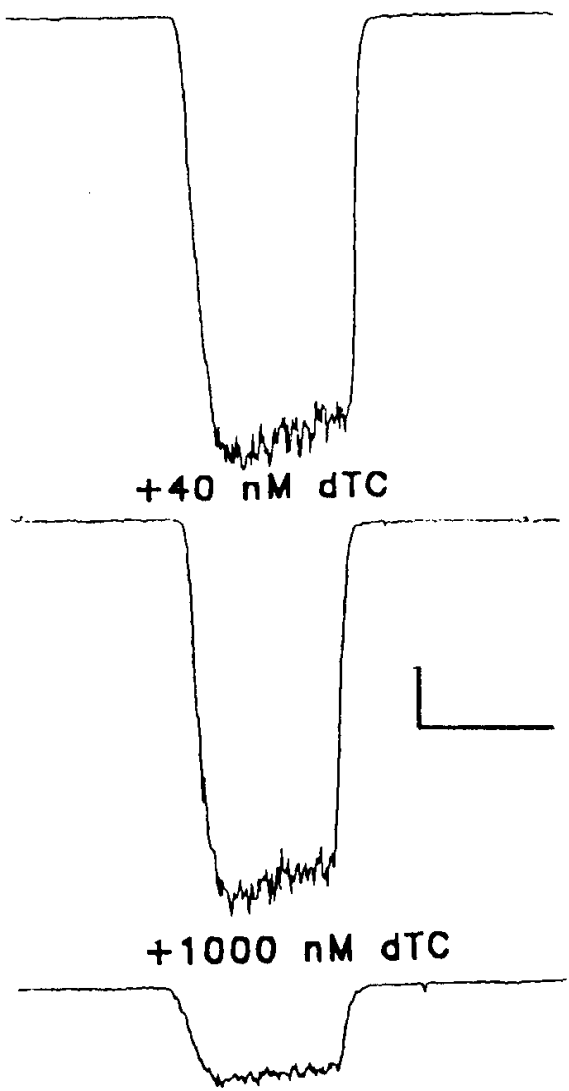

Figure 2. Currents elicited from Q-F18 cells by ACh may be blocked or enhanced by dTC: 40 nM ACh was applied to one cell (left column), alone (top trace), with $40 \mathrm{nM}$ dTC (second trace), or with $1000 \mathrm{nM}$ dTC (bottom trace); $1000 \mathrm{~nm}$ ACh was applied to a second cell (right column), alone (top trace), with $40 \mathrm{~nm}$ dTC (second trace), or with $1000 \mathrm{~nm}$ dTC (bottom trace). Note that dTC enhances responses to $40 \mathrm{~nm}$ ACh. Responses to $1000 \mathrm{nM} \mathrm{ACh}$ are blocked by both concentrations of dTC, although to a lesser extent than responses of Q-A33 cells (Fig. 1). Data filtered at 20 $\mathrm{Hz}$ and sampled at $20 \mathrm{msec}$ intervals. (Calibration: left column, $2 \mathrm{pA}, 2 \mathrm{sec}$; right column, $50 \mathrm{pA}, 2 \mathrm{sec}$.

with baseline taken as the mean of segments preceding and following the response.

Single-channel data were filtered at $3000 \mathrm{~Hz}$ and digitized at 20,000 $\mathrm{Hz}$. Events were detected using a midpoint threshold crossing method with the IPROC software package (provided by Dr. C. Lingle, Washington University School of Medicine, St. Louis, MO). Bursts were defined with a maximal intraburst closed time of $2 \mathrm{msec}$.

Two estimates were made of the relative probability of being open in single-channel records, for comparison to the whole-cell currents. The first $\left(\psi_{1}\right.$ in Table 1$)$ was made from the product of the arithmetic mean observed burst duration and the observed burst frequency, to obtain an estimate of the fraction of time in the record during which a channel was open (no correction was made for missed events). The second ( $\psi_{2}$ in Table 1) was made from the "all points" histogram by laking the fraction of events that were not in the Gaussian curve fit to the baseline peak. No correction was made in either case for the occurrence of multiple openings, but these were rare in all records.

Binding curves and single-channel dwell time histograms were fit using NFITs (provided by Dr. C. Lingle, Washington University School of Medicine). Theoretical curves shown on Figures 3, 5, and 6 were generated using QUATTRO (Borland International, Scott's Valley, CA), and parameters adjusted to provide a reasonable fit by eye.

\section{Results}

Curare can enhance responses of fetal $A C h R$ to $A C h$

The basic observations are shown in Figures 1 and 2. Q-A33 cells responded to perfused $\mathrm{ACh}$, and $\mathrm{dTC}$ reduced responses to $\mathrm{ACh}$ at any of the ACh and $\mathrm{d} \Gamma \mathrm{C}$ concentrations tested (Fig. 1). However, the responses of the fetal receptors expressed by
Q-F 18 cells depended on both the ACh and the dTC concentration (Fig. 2). At low concentrations of ACh and dTC, dTC enhanced the response to ACh. Responses were normalized to the response to a given concentration of $\mathrm{ACh}$ applied in the absence of $\mathrm{dTC}$, and are plotted as the relative response versus the concentration of dTC in Figure 3 (Q-A33, Fig. 3A; Q-F18, Fig. 3B).

We hypothesize that the observations could be explained if the dTC is a weak agonist of fetal receptors, and so some channel opening occurs when either two dTC or one dTC and one ACh molecule are bound. In contrast, channel opening for adult receptors does not occur with either one or two bound dTC molecules. This hypothesis was examined by determining the ability of dTC to bind to each type of receptor, the ability of dTC to activate receptors, and the effect of $\mathrm{dTC}$ on the responses to ACh.

\section{Channel block does not explain these effects of curare}

Curare is known to block open channels of nicotinic receptors with high affinity, in a voltage-dependent fashion (Colquhoun et al., 1979). However, at the concentrations of ACh and dTC used in the present experiments, this channel-blocking action cannot account for the observations. The apparent dissociation constant for channel block increases $e$-fold for a $30 \mathrm{mV}$ change to more positive membrane potential (Colquhoun et al., 1979). 

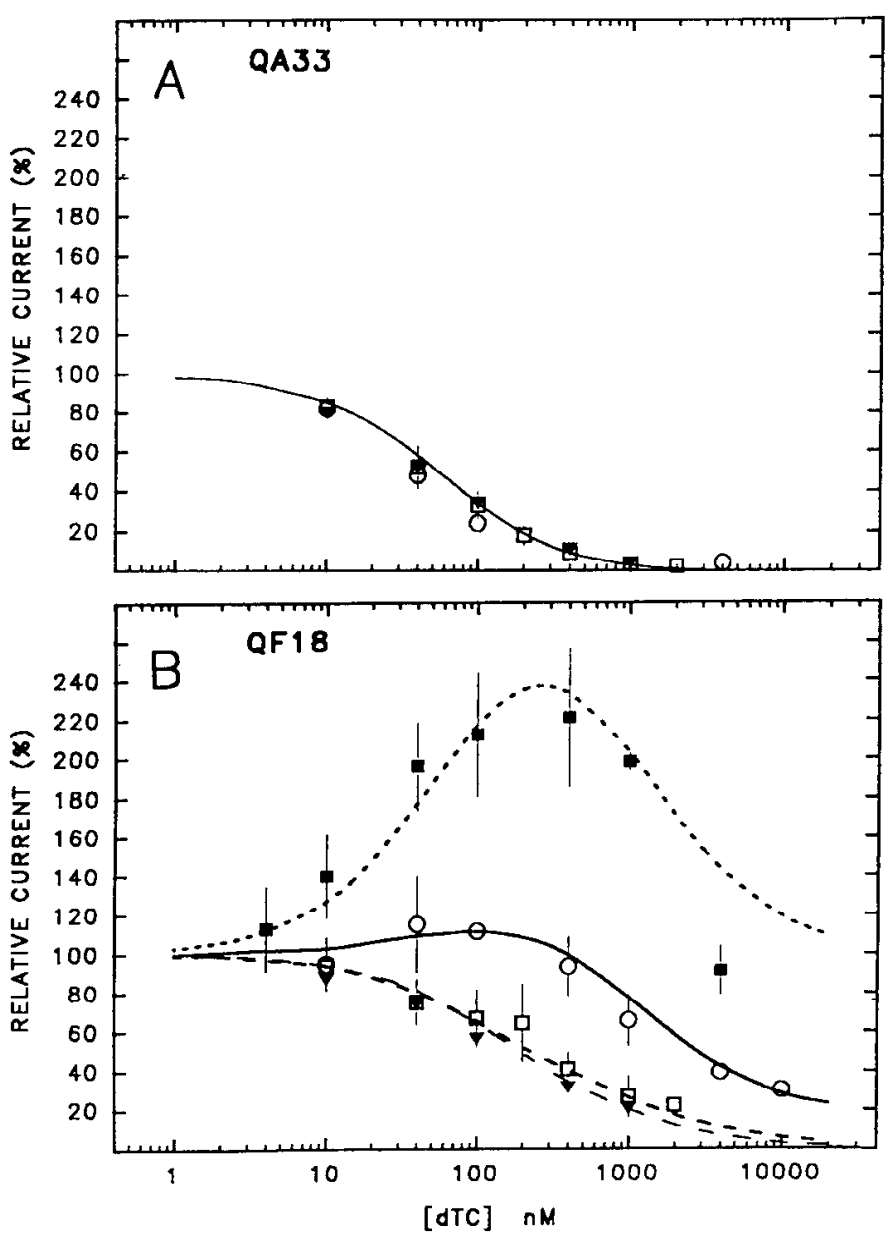

Figure 3. The effect of dTC at different concentrations on the response to various concentrations of $\mathrm{ACh}$. The normalized response to a mixture of ACh and dTC is plottcd as a function of dTC concentration. The data for a given concentration of $\mathrm{ACh}$ are normalized to the response in the absence of dTC (solid squares, $40 \mathrm{nM} \mathrm{ACh}$; open circles, $100 \mathrm{~nm}$ $\mathrm{ACh}$; open squares, $400 \mathrm{nM} \mathrm{ACh}$; solid triangles, $1000 \mathrm{nM} \mathrm{ACh}) . A$ shows the effect of dTC on responses of Q-A33 cells. At ACh concentrations of $100 \mathrm{nM}, 400 \mathrm{nM}$, and $1000 \mathrm{nM}$ the effects are indistinguishable. When fit with the Hill equation, the values for $K_{h}$ and $n$ were 38 $\mathrm{nM}, 1.06$ (100 nM ACh); $45 \mathrm{nM}, 0.99$ (400 nM ACh); $56 \mathrm{~nm}, 1.06$ (1000 nM ACh). The line was generated using scheme 1 as described in the Results. Only the prediction for $400 \mathrm{nM} A C h$ is shown as the lines predicted for $100 \mathrm{~nm}$ and $1000 \mathrm{~nm}$ ACh overlapped. $B$ shows relative responses elicited from Q-F18 cells. The dose-effect curve is clearly more complicated than that for Q-A33 cells. The lines have been generated using scheme 1. From top to bottom: short-dashed line, $40 \mathrm{~nm}$ $\mathrm{ACh}$; solid line, $100 \mathrm{~nm} \mathrm{ACh}$; medium-dashed line, $400 \mathrm{~nm} \mathrm{ACh}$; longdashed line, $1000 \mathrm{~nm}$ ACh. Points show mean $\pm \mathrm{SD}$ for ratios calculated for data from 2-22 cells. All data were obtained at $-50 \mathrm{mV}$.

The action of dTC on responses from Q-A33 cells at $-50 \mathrm{mV}$ (Fig. $3 A$ ) was described by the Hill equation with a $K_{D}$ of $46 \mathrm{nM}$ and Hill coefficient of 1.02 . Data at $-100 \mathrm{mV}$ were fitted with values of $45 \mathrm{~nm}$ and 0.93 , and at $+50 \mathrm{mV}$ with values of 49 $\mathrm{nM}$ and 0.87 , indicating no strong voltage dependence.

The dose-effect curves obtained from Q-F18 cells also show no significant voltage dependence. At $+50 \mathrm{mV}$ dTC enhances the responses to $40 \mathrm{~nm} \mathrm{ACh}$ to the same extent as at $-50 \mathrm{mV}$ : with $100 \mathrm{nM} \mathrm{dTC}$ the response is $218 \pm 26 \%$ (seven cells) that with $\mathrm{ACh}$ alone at $-50 \mathrm{mV}$, while at $+50 \mathrm{mV}$ it is $251 \pm 37 \%$ (three cells); with $400 \mathrm{nM}$ dTC the responses are $214 \pm 36 \%$ (eight cells) and $238 \pm 33 \%$ (three cells) $(P>0.2$ in each case

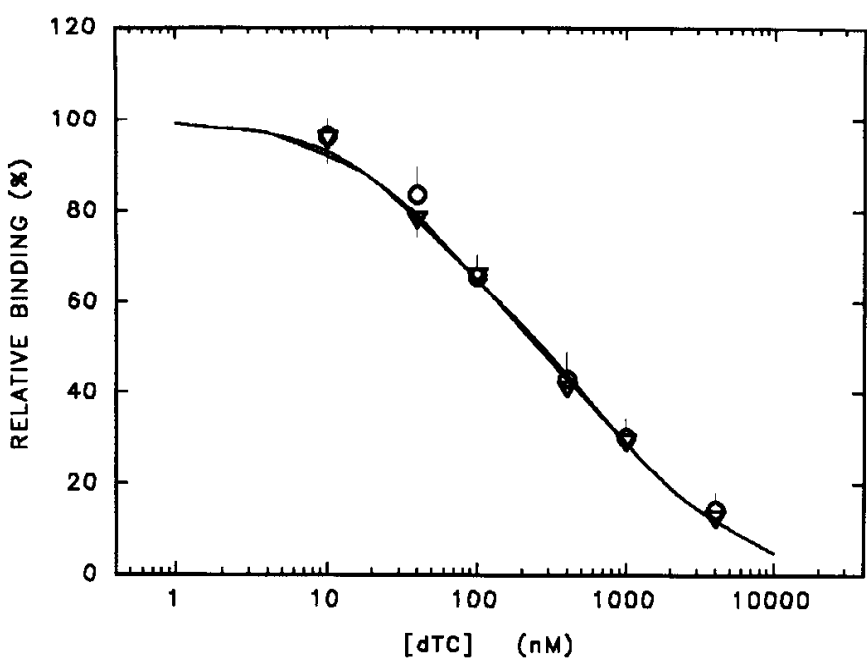

Figure 4. The inhibition of I-BTX binding is shown as a function of [dTC] for Q-A33 cells (triangles) and Q-F18 cells (circles). The data were first analyzed by fitting the Hill equation to the data, providing estimates for $K_{h}$ of $260 \pm 15 \mathrm{nM}$ and $n$ of $0.73 \pm 0.01$ (Q-A33 cells; mean $\pm \mathrm{SD}$, two curves fit) and $K_{h}$ of $303 \pm 65 \mathrm{nM}$ and $n$ of $0.75 \pm$ 0.02 (Q-F18 cells; three curves fit). The values did not differ significantly between the two cell types. Data were also fit assuming that two sites of different affinity for dTC were present in equal number, generating estimates for $\mathrm{L} 1$ of $60 \pm 16 \mathrm{nM}$ and L2 of $1031 \pm 83 \mathrm{nM}$ (Q-A33 cells; two curves fit) and $\mathrm{L} 1$ of $65 \pm 31 \mathrm{nM}$ and $\mathrm{L} 2$ of $1091 \pm 346 \mathrm{~nm}$ (QF1 8 cells; three curves fit). Again, the values did not differ significantly between the two cell types. The solid lines in the figure show the fits of the two-site model with these mean values.

by a two-tailed $t$ tcst). Similarly, responses to $1000 \mathrm{~nm} \mathrm{ACh}$ are blocked to the same extent at $+50 \mathrm{mV}$; with $100 \mathrm{nM}$ dTC the response is $56 \pm 5 \%$ (six cells) at $-50 \mathrm{mV}$ and $60 \pm 7 \%$ (two cells) at $+50 \mathrm{mV}$; with $400 \mathrm{nM}$ dTC the responses are $31 \pm 3 \%$ (six cells) and $34 \pm 4 \%$ (two cells) at $+50 \mathrm{mV}(P>0.2)$.

The lack of voltage dependence demonstrates that channel block by dTC is not significant for these results, and it will be discounted.

\section{Binding of $d T C$}

We determined the affinity of dTC for the AChR, by measuring its ability to reduce the initial rate of BTX binding. The results are shown in Figure 4, and indicate that binding of dTC to the receptors on Q-F18 and Q-A33 cells is indistinguishable (see also Gu et al., 1990; Kopta and Steinbach, 1994). The inhibition curves are relatively shallow (Hill slopes $<1$; see Fig. 4 legend). $\Lambda$ s previously reported (Sine and Taylor, 1981), the curves are consistent with the hypothesis that dTC binds to two sites with different affinities, present in equal numbers. Analysis of the data shown in Figure 4 provides estimates of the apparent highaffinity dissociation constant, L1, of $65 \pm 31 \mathrm{nM}$ (Q-F1 8 cells; mean $\pm \mathrm{SD} ; N=3$ binding curves) and $60 \pm 16 \mathrm{nM}$ (Q-A33 cells; $N=2$ ). Estimates of the low-affinity binding constant, $L 2$, are $1091 \pm 346 \mathrm{nM}(\mathrm{Q}-\mathrm{F} 18$ cells) and $1031 \pm 83 \mathrm{nM}$ (Q-A33 cells). These values do not differ significantly between the two cell types.

The values for L1 and L2 are smaller than those obtained previously (Kopta and Steinbach, 1994), which were L1 $=165$ $\pm 96 \mathrm{nM}$ and $\mathrm{L} 2=2917 \pm 1154 \mathrm{nM}(\mathrm{Q}-\mathrm{A} 33$ cells; three curves fit) and $\mathrm{Ll}=156 \pm 49 \mathrm{nM}$ and $\mathrm{L} 2=3841 \pm 1374 \mathrm{nM}(\mathrm{Q}-\mathrm{F} 18$ cells; three curves fit). The difference is consistent, although it is only significant for the constants obtained from Q-F18 cells 

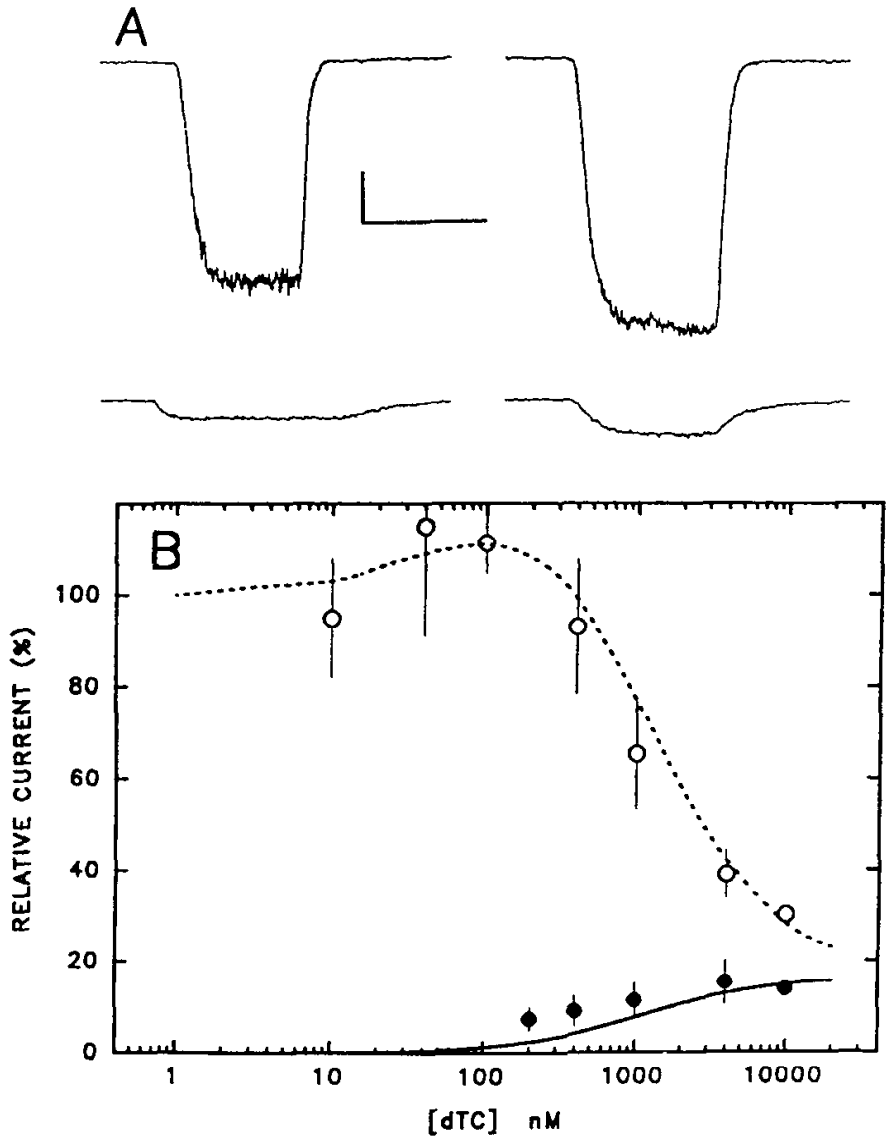

Figure 5. dTC can elicit currents from Q-F18 cells. $A$ shows wholecell currents recorded from a cell in response to $100 \mathrm{~nm}$ ACh (upper left), $100 \mathrm{~nm}$ ACh plus $200 \mathrm{~nm}$ dTC (upper right), $200 \mathrm{~nm}$ dTC (lower left), and 1000 nм dTC (lower right). Data were filtered at $20 \mathrm{~Hz}$ and sampled at $20 \mathrm{msec}$ intervals. Calibration: $50 \mathrm{pA}, 5 \mathrm{sec}$. $B$ shows the relative response to various concentrations of dTC (solid circles), normalized to the response of the cell to $100 \mathrm{nM} \mathrm{ACh}$. Open circles show the relative response to $100 \mathrm{nM} A C h$ plus various concentrations of dTC (replotted from Fig. $3 B$ ). The solid line through the responses to dTC alone was generated assuming that channels open only after two dTC molecules have bound with dissociation constants obtained from binding data (see Results). The dashed line through responses to 100 $\mathrm{nM} \mathrm{ACh}+\mathrm{dTC}$ is replotted from Figure $3 B$.

( $p<0.05$, two-tailed $t$ test). The smaller values obtained in the present experiments provide a better description for the block of responses on Q-A33 cells (compare the present Fig. $3 A$ to Fig. $4 C$ of Kopta and Steinbach, 1994), and for the dose-effect relationship with Q-F18 cells. We have no explanation for the difference in estimated dissociation constant. The difference probably does not arise from the selection procedure, since in one experiment with unselected Q-F18 cells we found affinities of $70 \mathrm{~nm}$ and $600 \mathrm{nM}$. It does not arise from the batch of dTC, since similar results were obtained using the original lot of dTC as well as a new one. In one experiment with selected Q-F18 cells using bicarbonate-buffered EBSS (rather than HEPES buffer), values of $68 \mathrm{~nm}$ and $1431 \mathrm{~nm}$ were obtained.

\section{Activation of currents by $d T C$}

The relative abilities of $\mathrm{dTC}$ and ACh to activate fetal and adult AChR were assessed by applying $100 \mathrm{~nm}$ ACh or various concentrations of dTC to individual cells. The response of Q-A33 cells to dTC was less than $1 \%$ of the response to $100 \mathrm{~nm} \mathrm{ACh}$ and could not be accurately measured, although in somc cells occasional single-channel currents appeared during the applications of dTC (data not shown; see Trautmann, 1983). Q-F18 cells, on the other hand, produced clear responses (Fig. 5). The solid line in Figure 5 was generated (see below) with the assumption that channels opened only after two dTC molecules had bound to a receptor, and that the dissociation constants determined from the data in Figure 4 were appropriate.

\section{Effect of dTC on the dose-response relationship for ACh}

The response to low concentrations of $\mathrm{ACh}$ increases more than linearly with the concentration of $\mathrm{ACh}$ applied for both Q-A33 and Q-F18 cells (Fig. 6; Kopta and Steinbach, 1994). Logarithmic plots of the data from both types of cells show some degree of curvature. For Q-A33 cells, the slope from $40 \mathrm{~nm} \mathrm{ACh}$ to $200 \mathrm{nM} \mathrm{ACh}$ is $1.4 \pm 0.2(N=2)$, which is significantly less than the slope between 100 and $400 \mathrm{~nm}(1.8 \pm 0.1, N-16 ; p$ $<0.01$ by the $t$ test). The slope between $200 \mathrm{~nm}$ and $1000 \mathrm{~nm}$ is also slightly less than that between 100 and $400 \mathrm{~nm}(1.7 \pm$ $0.03, N=4 ; p<0.05$ ). In contrast, for data obtained from Q-F1 8 cells the slope between $40 \mathrm{nM}$ and $200 \mathrm{~nm}$ ACh $(1.9 \pm$ $0.1, N=7)$ is greater than the slope between $100 \mathrm{~nm}$ and 400 nM $(1.8 \pm 0.1, N=20 ; p<0.05)$. For data from Q-F18 cells the slope between $200 \mathrm{~nm}$ and $1000 \mathrm{~nm}(1.6 \pm 0.1, N-9)$ is significantly reduced from the slope between 100 and 400 nм $(p<0.001)$

The addition of dTC does not alter the slope of the doseresponse curve for $\mathrm{ACh}$ obtained from Q-A33 cells, while it reduces the slope for Q-F1 8 cells (Kopta and Steinbach, 1994; data replotted in Fig. 6). The reduction in slope reflects both an enhancement of response at low [ACh] and [dTC] and a reduction at higher concentrations, as seen in Figures 2 and 3.

\section{Single-channel currents}

Outside-out patches excised from Q-F18 cells were exposed to ACh alone, dTC alone, and a mixture of ACh and dTC. Singlechannel currents elicited by ACh, dTC, or ACh + dTC had identical amplitudes (Fig. 7). The mean single-channel current amplitudes were compared by applying ACh alone, dTC alone, and $\mathrm{ACh}$ plus dTC to outside-out patches. The mean amplitude for currents elicited by dTC alone was $0.99 \pm 0.01$ that for ACh alone (10 patches), and that for currents elicited by ACh plus $\mathrm{dTC}$ was $1.01 \pm 0.01$ ( 7 patches). Subconductance levels were not seen in any of the records, so they are certainly not common when receptors are activated in the presence of dTC. However, subconductance states have been reported to be rare at dTC concentrations less than $10 \mu \mathrm{M}$ (Takeda and Trautmann, 1984; Strecker and Jackson, 1989), and only low concentrations were used in the present studies.

Further analyses were made of the responses of patches exposed to $100 \mathrm{~nm}$ ACh, $100 \mathrm{~nm}$ ACh plus $400 \mathrm{~nm}$ dTC, and 400 nM dTC. These concentrations were chosen because the wholecell response to $100 \mathrm{~nm} \mathrm{ACh}+400 \mathrm{~nm}$ dTC is essentially equal to that to $100 \mathrm{nM}$ ACh alone $(93 \pm 14 \%, N=8$ cells; see Fig. $3 B$ ). When the same patch was exposed to $\mathrm{ACh}$ alone, to $\mathrm{ACh}$ $+\mathrm{dTC}$, and to dTC alone the frequency of bursts was higher in the mixture of $\mathrm{ACh}+\mathrm{dTC}$ than in $\mathrm{ACh}$ alone or in $\mathrm{dTC}$ alone (Fig. 7, Table 1A). The bursts also had different mean durations. Those elicited by ACh alone had the longest mean durations while those by dTC alone had the briefest mean duration (Fig. 8, Table $1 A$ ).

The whole-cell response measures the product of the number 

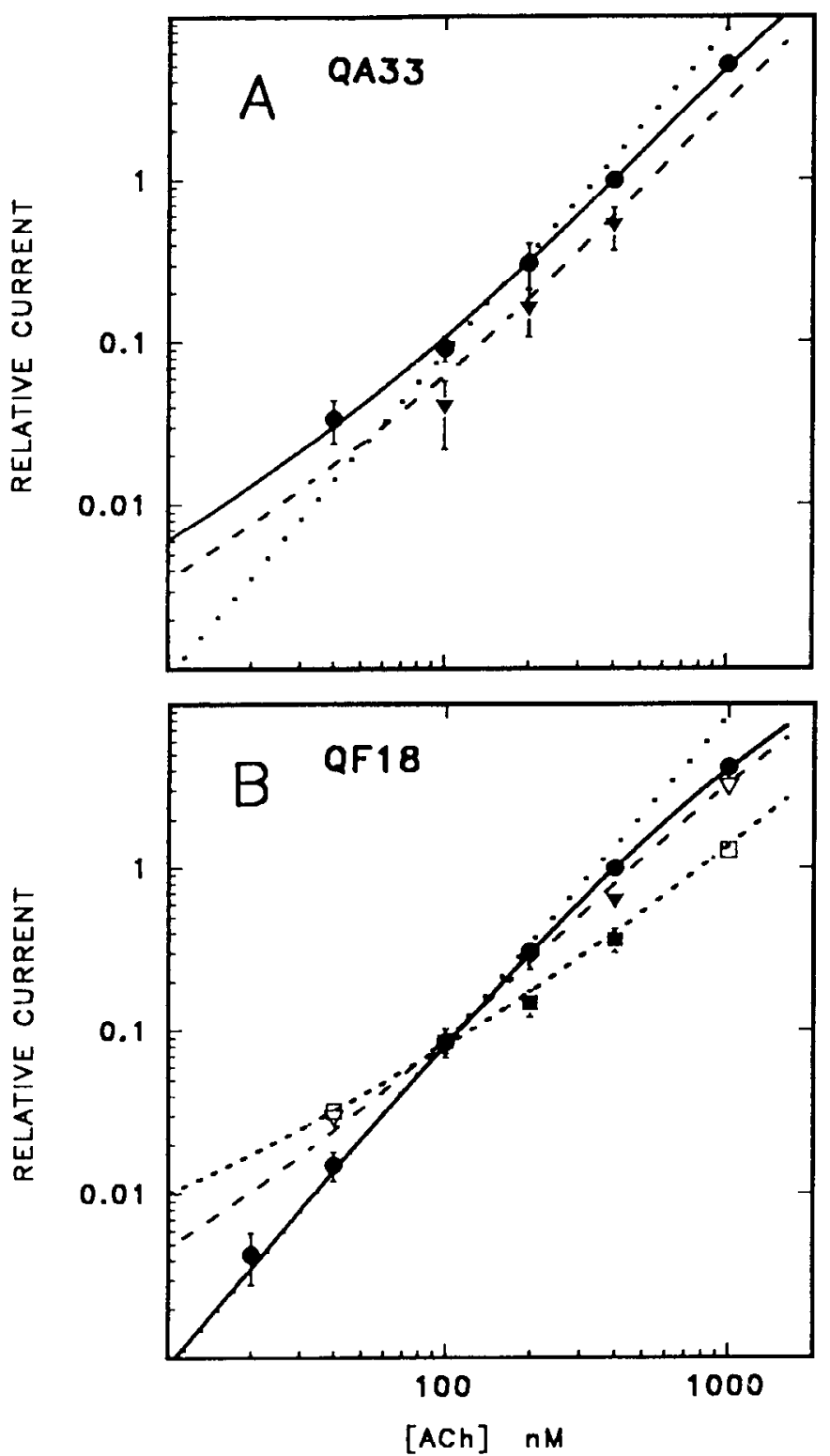

Figure 6. The dose-response relationship at low [ACh], in the absence and presence of dTC. The responsc to ACh, normalized to the response a cell gave to $400 \mathrm{nM} \mathrm{ACh}$, is plotted logarithmically against the concentration of $\mathrm{ACh}(A, \mathrm{Q}-\mathrm{A} 33$ cells; $B, \mathrm{Q}-\mathrm{F} 18$ cells). Points shown as solid symbols with error bars were measured (circles, 0 dTC; triangles, $40 \mathrm{~nm}$ dTC; squares, $400 \mathrm{~nm}$ dTC; note that $A$ only shows data with 0 dTC and $40 \mathrm{~nm} \mathrm{dTC).} \mathrm{The} \mathrm{points} \mathrm{shown} \mathrm{as} \mathrm{open} \mathrm{symbols} \mathrm{in} B$ were calculated from the dose-effect relationship for dTC shown in Figure $3 B$ and the dose-response curve for $\mathrm{ACh}$ alone shown here. The solid lines through the responses to ACh alone were fit as described in the Results. The dotted lines show a slope of 2 , passing through the response to $100 \mathrm{~nm} \mathrm{ACh}$, for comparison. The long-and short-dashed lines were generated as described in the Results, based on the analysis of responses to ACh alone, dTC alone (Fig. 5), and ACh + dTC (Fig. 3) (long-dashed line, ACh plus $40 \mathrm{~nm}$ dTC; short-dashed line, ACh plus $400 \mathrm{~nm} \mathrm{dTC}$ ). $A$, Data from Q-A33 cells. The responses at low ACh are larger than expected (compare to dotted line), indicating that some activation of AChR with one bound ACh molecule occurs (R1 > 0; solid line generated with $R 1=0.0075$ ). Responses to $1000 \mathrm{~nm} A C h$ fall somewhat below the dotted line, consistent with the idea that the dissociation constant for the high-affinity binding of $\mathrm{ACh}$ is $5 \mu \mathrm{M}$ (see solid line). Responses to $\mathrm{ACh}+\mathrm{dTC}$ are equivalently depressed at all concentrations tested indicating that no activation occurs with one or two dTC molecules bound (see long-dashed line). B, Data from Q-F18 cells. Note that the responses to low concentrations of $\mathrm{ACh}$ alone fall along the line with slope of 2 , indicating that essentially no activation of $A C h R$ with
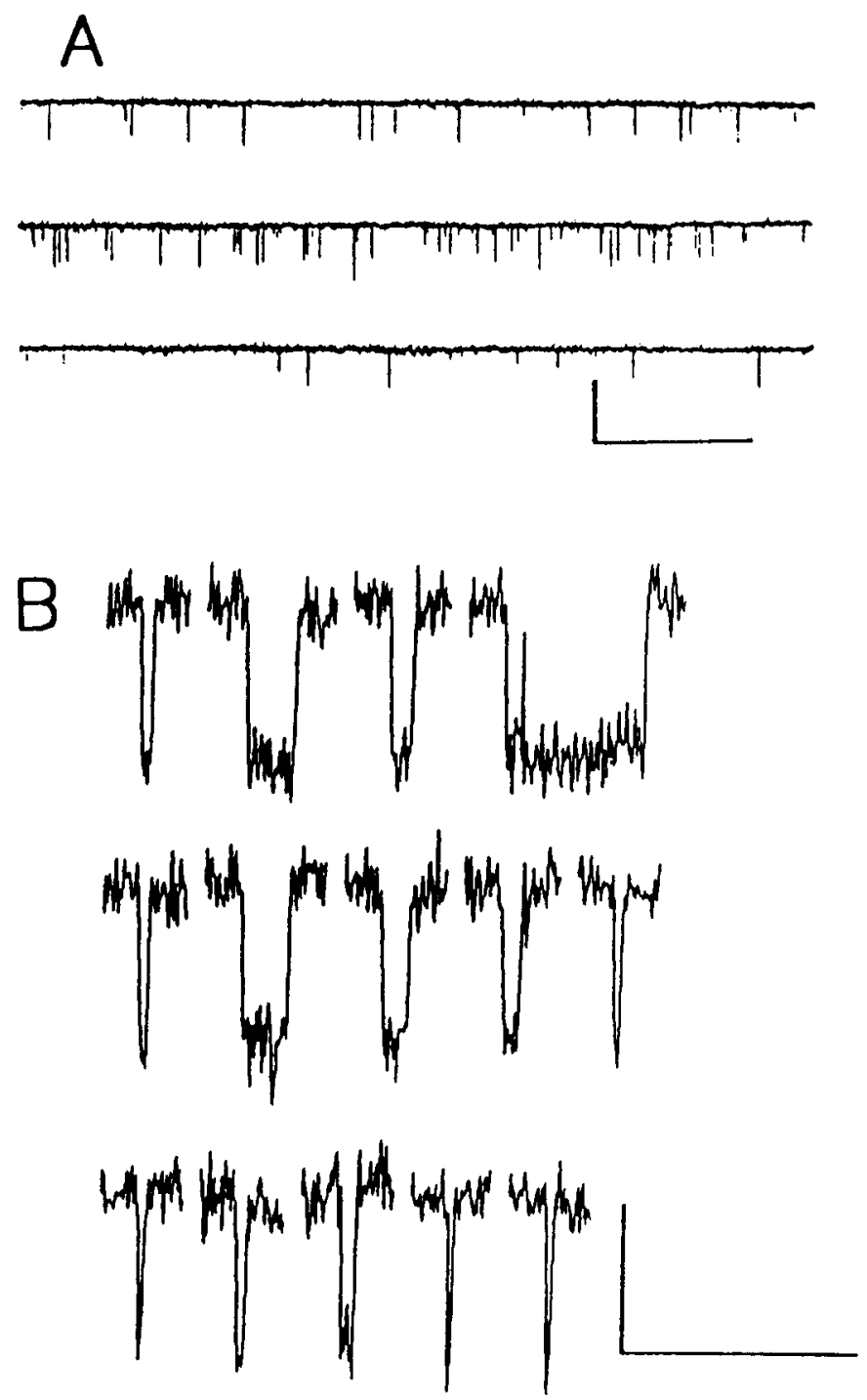

Figure 7. Single-channel currents elicited in an outside-out patch by ACh, dTC, and a mixture. $A$ shows traces from one outside-out patch exposed to $100 \mathrm{~nm} \mathrm{ACh}$ (top trace), $100 \mathrm{~nm}$ ACh plus $400 \mathrm{~nm}$ dTC (middle trace), and $400 \mathrm{nM}$ dTC (bottom trace). The burst frequency is highest in the mixture and lowest in dTC. Data were filtered at 3000 $\mathrm{Hz}$ and digitized at $50 \mu \mathrm{sec}$ intervals. Note the presence of some $60 \mathrm{~Hz}$ line-frequency interference in the traces. $B$ shows representative singlechannel currents in the three conditions. Calibration: $A, 5 \mathrm{pA}, 1 \mathrm{sec} ; B$, $2 \mathrm{pA}, 10 \mathrm{msec}$

of available receptors times the probability a receptor is open ( $\mathrm{NP}_{o}$; the data indicate that channel conductances are identical). Two estimates of $\mathrm{NP}_{o}$ were made from the single-channel records (see Materials and Methods). The data in Table $1 A$ dem-

one bound $\mathrm{ACh}$ molecule occurs $(\mathrm{R} 1=0 ;$ see solid line $)$. The response to $1000 \mathrm{~nm}$ ACh falls below the line with slope 2 (to a greater extent than do responses of Q-A33 cells shown in $A$ ), consistent with a highaffinity dissociation constant of about $1 \mu \mathrm{M}$. Furthermore, responses to mixtures of $\mathrm{ACh}$ and $\mathrm{dTC}$ can actually be enhanced, indicating that activation of fetal AChR can occur with two dTC molecules or one dTC and one $\mathrm{ACh}$ molecule bound $(\mathrm{P} 1>0, \mathrm{P} 3>0$; see short- and longdashed lines), Solid symbols show mean \pm SD for 3-17 measurements. Data for ACh plus $40 \mathrm{~nm}$ dTC and $400 \mathrm{~nm}$ dTC (solid triangles and solid squares) are replotted from Kopta and Steinbach (1994). 
Table 1. Properties of single-channel currents elicited by ACh alone, dTC alone, and a mixture of ACh and dTC

$A$. Observed values (relative to ACh alone)

\begin{tabular}{lllll} 
& $\tau_{B}$ & $f_{B}$ & $\psi_{1}$ & $\psi_{2}$ \\
\hline $\mathrm{ACh}+\mathrm{dTC}(N=6)$ & $0.6 \pm 0.1^{*}$ & $2.7 \pm 0.8^{*}$ & $1.5 \pm 0.2^{*}$ & $1.3 \pm 0.5$ \\
$\mathrm{dTC}(N=3)$ & $0.4 \pm 0.1^{*}$ & $0.6 \pm 0.3$ & $0.2 \pm 0.1^{*}$ & $0.3 \pm 0.2^{*}$
\end{tabular}

$B$. Results of fitting distributions with sums of two exponential components

Time constants

\begin{tabular}{llll} 
& $\tau_{b}$ (msec) & $\tau_{1}$ (msec) & Fraction long \\
\hline $\operatorname{ACH}(N=4)$ & $0.39 \pm 0.07$ & $2.5 \pm 0.4$ & $0.51 \pm 0.12$ \\
$\operatorname{ACh}+\operatorname{dTC}(N=5)$ & $0.35 \pm 0.06$ & $2.2 \pm 1.3$ & $0.14 \pm 0.03 \dagger$ \\
$\operatorname{dTC}(N=3)$ & $0.30 \pm 0.08$ & - & -
\end{tabular}

Relative calculated frequencies

\begin{tabular}{lll} 
& Brief bursts & Long bursts \\
\hline$(\mathrm{ACh}+\mathrm{dTC}) / \mathrm{ACh}(N=4)$ & $5.8 \pm 3.6^{*}$ & $1.0 \pm 0.7$ \\
$(\mathrm{ACh}+\mathrm{dTC}) / \mathrm{dTC}(N=3)$ & $3.3 \pm 1.1^{*}$ & - \\
$\mathrm{dTC} / \mathrm{ACh}(N=3)$ & $1.1 \pm 0.6$ & -
\end{tabular}

Outside-out patches were excised from Q-F18 cells, and exposed to solutions containing $100 \mathrm{nM} \mathrm{ACh}, 100 \mathrm{nM} \mathrm{ACh}+$ $400 \mathrm{~nm} \mathrm{dTC}$, and $400 \mathrm{nM}$ dTC. $A$ summarizes some experimentally observed values. The data are presented as the ratio to the value from the same patch for data obtained when $\mathrm{ACh}$ alone was applied. The ratios for arithmetic mean burst duration $\left(\tau_{B}\right)$ and observed frequency $\left(f_{B}\right)$ are shown. Two estimates of equilibrium activation were calculated (see Materials and Methods): $\psi 1$ is the product $\tau_{B} \times f_{B}$, and $\psi 2$ is the fraction of time open from an "all points" histogram. $B$ presents the results of fitting the sum of exponential components to distribution of burst durations, for records containing more than 200 bursts elicited by $100 \mathrm{nM} \mathrm{ACh}$ (see Fig. 8). The mean time constant for brief- $\left(\tau_{b}\right)$ and long- $\left(\tau_{1}\right)$ duration components are given for $\mathrm{ACh}$ alone and $\mathrm{ACh}+\mathrm{dTC}$; only a brief-duration component was found in records obtained with dTC alone at this concentration. The fraction of the total number of events in the theoretical distribution that fell in the long-duration component is shown. The frequency of a class of events was calculated from the area of the fit component and the record length, for each patch. - indicates that no long-duration bursts could be characterized in 400 nм dTC.

* Differs from 1.0 with $P<0.05$ using a two-tailed $t$ test.

$\dagger$ Differs from that obtained with ACh alone with $P<0.05$.

onstrate that the increased burst frequency and reduced burst duration in the mixture of $\mathrm{ACh}+\mathrm{dTC}$ offset each other. The mean values of $\mathrm{NP}_{o}$ were very similar for $\mathrm{ACh}$ and $\mathrm{ACh}+\mathrm{dTC}$ (ratios close to 1; see Table 1 $A$ ). The binding data (Fig. 4) demonstrate that most $\mathrm{AChR}$ have bound dTC at this concentration. Hence, the relatively small increase in burst frequency in $\mathrm{ACh}$ $+\mathrm{dTC}$ implies that the opening rate for heteroliganded receptors is lower than that for ACh diliganded receptors.

The distributions of burst durations could be described by the sums of two exponentials in the presence of $\mathrm{ACh}$ or $\mathrm{ACh}$ $+\mathrm{dTC}$, whereas the distributions in $\mathrm{dTC}$ showed a single briefduration component (Fig. 8). The time constants of the brief component were similar for all three conditions, and the time constants of the long-duration component were similar for $\mathrm{ACh}$ and $\mathrm{ACh}+\mathrm{dTC}$ (Figure 8, Table $1 B$ ). However, the proportions of bursts falling in the brief and long components differed systematically between the three conditions: essentially all bursts elicited by dTC were of brief duration; $10 \%$ were long in $\mathrm{ACh}$ $+\mathrm{dTC}$, while half were long in ACh (Fig. 8, Table $1 B$ ). Hence, most heteroliganded receptors have a brief burst duration similar to that of dTC homoliganded receptors. However, since the binding data indicate that most $\mathrm{AChR}$ have at least one bound dTC molecule at the concentration of dTC used, it is very likely that some of the long-duration bursts in $\mathrm{ACh}+\mathrm{dTC}$ arise from heteroliganded receptors as well. An earlier study of current relaxations after voltage jumps in the presence of mixtures of agonists (Trautmann and Feltz, 1980) concluded that the burst duration of heteroliganded receptors was closer to that of the pure agonist producing the briefer bursts.

\section{Correlation between binding and functional data}

The data were analyzed to relate the binding of dTC to the functional consequences of the binding. The hypothetical scheme shown in Figure 9 was used in this analysis (scheme 1). Although scheme 1 has many parameters, it is the simplest scheme that incorporates the observations that there are two binding sites on a single $\mathrm{AChR}$, which have different affinities for ligands. The data have not been acquired over a sufficient range of concentrations to allow unconstrained fitting of the predictions of the scheme to the data. However, the dissociation constants for dTC determined from the binding data can account for the functional data when reasonable values for other parameters are used.

In Figure 9, $\mathrm{R}$ represents an AChR. Each AChR has two sites that can bind either ACh or dTC. It is assumed (see Discussion) that the sites have different dissociation constants for both $\mathrm{ACh}$ and dTC. There are four dissociation constants: $\mathrm{K} 1$ and $\mathrm{K} 2$ are the high- and low-affinity dissociation constants for ACh and L1 and L2 the constants for dTC. As indicated in Figure 9, it is assumed that the site that has a high affinity for dTC also has a high affinity for ACh. The ion channels can open $\left(R^{*}\right.$ in Fig. 9). There are four opening ratios shown (the ratio of the channel opening rate to the channel closing rate): R3 for AChR diliganded with ACh, P3 for AChR diliganded with dTC, R1 for AChR with one bound ACh molecule (assumed identical for AR and RA), and P1 for AChR with one bound ACh and one bound dTC (assumed identical for ARC and CRA). The opening 

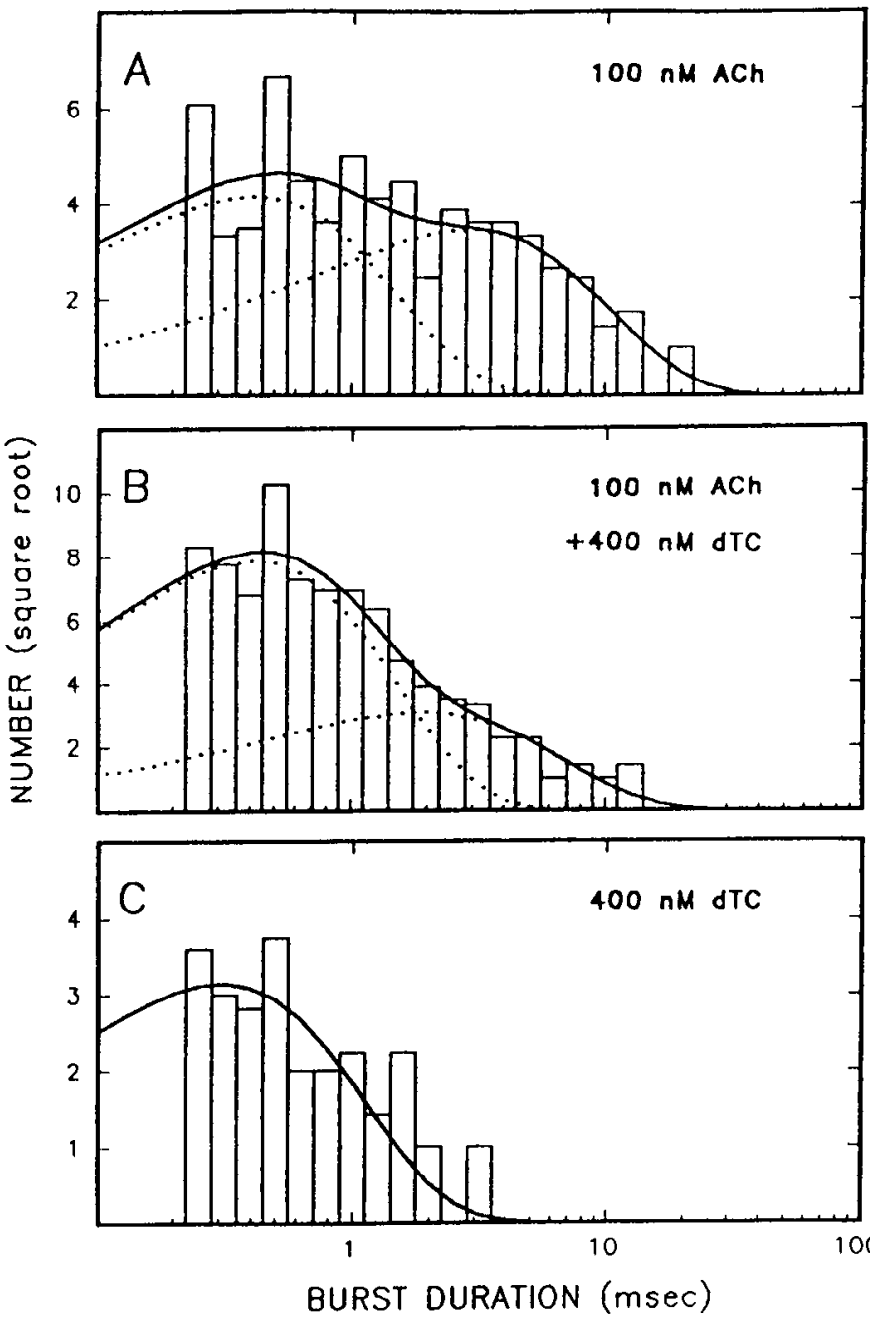

Figure 8. Burst duration histograms for single channels evoked by 100 nm ACh $(A), 100 \mathrm{~nm}$ ACh plus $400 \mathrm{~nm}$ dTC $(B)$, and $400 \mathrm{~nm} \mathrm{dTC}(C)$. The solid lines show the sum of two exponentials $(A, B)$ or a single exponential $(C)$; the dotted lines show individual components in $A$ and $B$. Histograms are displayed with square root scaling for the ordinate and logarithmic scaling for the abscissa (Sigworth and Sine, 1987). Note that the mean duration for an exponential component occurs at the peak value in these plots, and that the presence of multiple components is apparent from the breadth of the distributions. The histograms contained 275, 545, and 64 bursts, respectively, and are derived from the records shown in Figure 7. The components fit to the distributions had the following time constants, percentages of total calculated area, and calculated frequencies, for ACh alone: $0.37 \mathrm{msec}, 59 \%, 1.9 \mathrm{sec}^{-1}$ and $2.6 \mathrm{msec}, 41 \%, 1.3 \mathrm{sec}^{-1}$; ACh plus dTC: $0.37 \mathrm{msec}, 87 \%, 11.1 \mathrm{sec}^{-1}$ and $1.7 \mathrm{msec}, 13 \%, 1.7 \mathrm{sec}^{-1}$; dTC alone: $0.27 \mathrm{msec}, 100 \%, 3.1 \mathrm{sec}^{-1}$

ratio has also been termed efficacy (Colquhoun and Sakmann, 1985).

The apparent dissociation constants for dTC binding ( $\mathrm{L} 1$ and L2) were set to the values obtained in the binding experiments. Other parameters were then estimated by adjusting them one at a time to provide an adequate fit by eye, as described below.

\section{Fetal-type receptors}

The first step was to examine the dose-response curve for ACh alone (Fig. $6 B$, solid symbols and solid line). A logarithmic doseresponse plot is, in general, nonlinear. The slope at low [ACh] approaches the minimal number of bound $\mathrm{ACh}$ molecules required to produce measurable probability a receptor will have

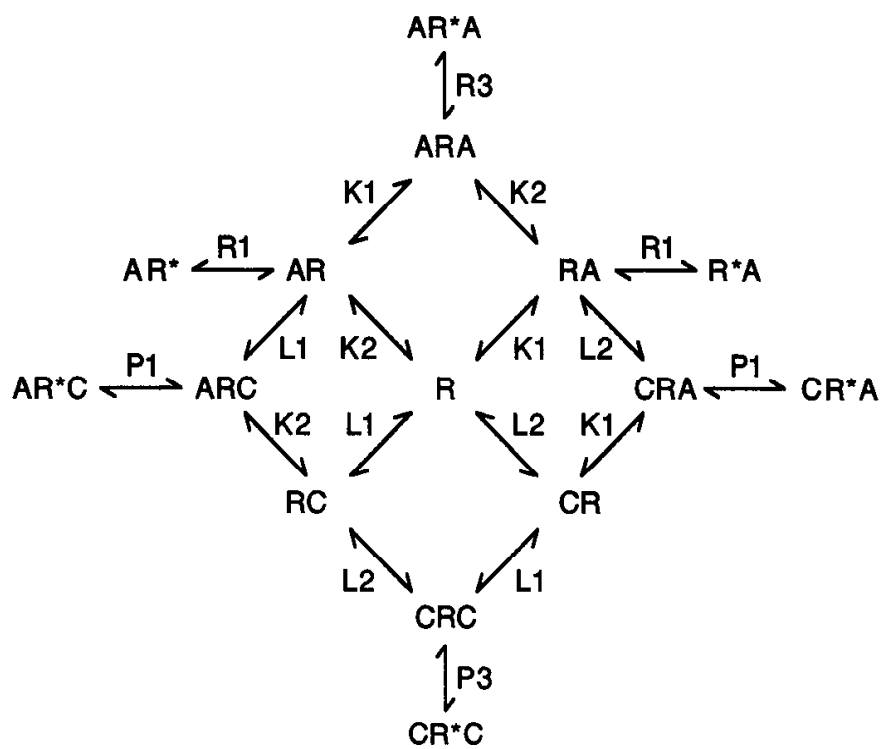

Figure 9. The reaction scheme used in analyzing the data. See the text for further description of the scheme and the determination of parameter values. The major features of this scheme are that $\operatorname{dTC}(C)$ and $\mathrm{ACh}$ $(A)$ bind competitively to two sites on an individual AChR $(R)$. dTC binds to the two sites on the ACh receptor with affinities $L 1$ and $L 2$. ACh binds with affinities $K 1$ and $K 2$. In the calculations it was assumed that the high-affinity dTC site is the same site as the high-affinity ACh site. Receptors with two ACh molecules bound that have a closed channel $(A R A)$ open (to $A R^{*} A$ ) with a ratio of opening rate constant to closing rate constant $R 3$, while receptors with two dTC molecules bound (CRC) have an opening ratio $P 3$. Receptors with one bound $A C h$ molecule have an opening ratio $R l$, assumed identical for $A R$ and $R A$. Heteroliganded receptors have an opening ratio $P 1$, assumed to be identical for both $C R A$ and $A R C$. The parameter values used in generating the curves for data from Q-A33 cells shown in Figures $3 A$ and $6 A$ are L1 $=60 \mathrm{nM}, \mathrm{L} 2=1031 \mathrm{nM}, \mathrm{Kl}=5 \mu \mathrm{M}, \mathrm{K} 2=500 \mu \mathrm{M}, \mathrm{Pl}=0, \mathrm{P} 3=0$, $R 1=0.0075$, and $R 3=40$. The parameter values used in generating the curves for data from Q-F18 cells shown in Figures $3 B, 5 B$, and $6 B$ are $\mathrm{L} 1=65 \mathrm{nM}, \mathrm{L} 2=1091 \mathrm{nM}, \mathrm{K} 1=1 \mu \mathrm{M}, \mathrm{K} 2=500 \mu \mathrm{M}, \mathrm{P} 1=0.42$, $\mathbf{P} 3=0.0003, \mathrm{R} 1=0$, and $\mathrm{R} 3=100$.

an open channel; for Q-F18 cells the slope approaches a value of 2 (Fig. $6 \mathrm{~B}$, dotted line). This suggests that the contribution of open channels with one bound ACh molecule is negligible. $\mathrm{R} 1$ was therefore set to 0 (the maximal value for $\mathrm{R} 1$ consistent with the data in Fig. $6 B$ is $1 \times 10^{-3}$, about $1 \times 10^{-5}$ that for AChR with two bound ACh). At high [ACh] the slope will decrease to 0 (as binding and activation saturate), or even to negative values if block or desensitization develop. The curvature in the dose-response relationship shown in Figure $6 B$ can be described using a value for $\mathrm{K} 1$ of $1 \mu \mathrm{M}$ (solid line). The values of $\mathrm{K} 2$ and $\mathrm{R} 3$ cannot be determined from the data in Figure $6 B$, since the maximal response was not determined and over this concentration range they appear only as the ratio R3: $\mathrm{K} 2$. However, studies of the peak currents and opening rates seen in response to rapid applications of $\mathrm{ACh}$ to patches excised from Q-F18 cells (D. J. Maconochie and J. H. Steinbach, unpublished observations) indicate that the fetal AChR have lowand high-affinity sites for $\mathrm{ACh}$, and that the channel opening rate constant is much larger than the closing rate constant. The value for $\mathrm{K} 1$ is in the range of $1-10 \mu \mathrm{M}$ (as indicated from the data in Fig. $6 B$ ) and that for $\mathrm{K} 2$ is close to $1 \mathrm{~mm}$. For the succeeding analysis, it was assumed that $\mathrm{K} 2$ has a value of 500 $\mu \mathrm{M}$ and $\mathrm{R} 3$ of 100 . 
The next step was to fix the dissociation constants for dTC at the values obtained in binding experiments (Fig. $4 ; \mathrm{Ll}=65$ $\mathrm{nm}, \mathrm{L} 2=1091 \mathrm{~nm})$. The opening ratio for receptors occupied by two dTC molecules was then estimated from the maximal current elicited by dTC alone (Fig. $5 B$ ). This resulted in a value of $3 \times 10^{-4}$ (i.e., about $3 \times 10^{-6}$ that for AChR with two bound ACh molecules). The final step was to estimate the value for P1 from the dose-effect curves for dTC on currents elicited by $\mathrm{ACh}$ (Fig. $3 B$ ). This was done by adjusting the value of $\mathrm{P} 1$ to provide an adequate description of the data obtained at all $\mathrm{ACh}$ and dTC concentrations shown, while keeping values for all the other parameters constant. This resulted in a value of $\mathrm{P} 1=0.42$ (about $4 \times 10^{-3}$ that for AChK with two bound ACh molecules).

In sum, values of $K 1, R 1, P 1$, and $P 3$ were estimated from the data in figures $3 B, 6 B$, and $7 B$, while values for $\mathrm{K} 2$ and $\mathrm{R} 3$ were assumed. The values used were $\mathrm{K} 1=1 \mu \mathrm{M}, \mathrm{K} 2=500 \mu \mathrm{M}$, $\mathrm{L} 1=65 \mathrm{nM}, \mathrm{L} 2=1091 \mathrm{nM}, \mathrm{R} 1=0, \mathrm{R} 3=100, \mathrm{P} 1=0.42$, and $\mathrm{P} 3=0.0003$. These values produced reasonable descriptions of the relative responses as a function of [dTC] (Fig. 5B) and [ACh] (Fig. 6B), as well as the effects of dTC on responses to ACh (Figs. 3B, 6B).

\section{Adult-type receptors}

This scheme is simpler for the adult-type receptors expressed by Q-A33 cells, as there was no evidence that dTC produced appreciable activation of AChR. Hence, P3 was set to 0 (subsequent modeling suggested that the upper limit for P3 would be $\left.5 \times 10^{-6}\right)$. Similarly, there was no indication that channels opened when one $\mathrm{ACh}$ and one $\mathrm{dTC}$ were bound, so $\mathrm{Pl}$ was also set to 0 (again, an upper limit appears to be about $5 \times$ $\left.10^{-4}\right)$. The dissociation constants for dTC were taken from the binding data (Fig. 4), as $\mathrm{L1}=60 \mathrm{nM}$ and $\mathrm{L2}=1031 \mathrm{nM}$.

At low [ACh], the logarithmic ACh dose-response curve for Q-A33 cells has a slope less than 2 (Fig. $6 \mathrm{~A}$ ). The reduction in slope suggests that there is a measurable contribution of open channels from $\mathrm{AChR}$ with only one bound $\mathrm{ACh}$. In addition, the reduction at higher [ACh] is less marked than for Q-F18 cells (compare to Fig. $6 B$ ), suggesting that the value of $\mathrm{K} 1$ for adult-type $A C h R$ is larger. The dose-response relationship could be described using values for $\mathrm{K} 1$ of $5 \mu \mathrm{M}$ and for $\mathrm{R} 1$ of $7.5 \times$ $10^{-3}$ (solid line in Fig. 6A). However, these values could not be estimated separately because over the concentration range tested they appear largely as the ratio $\mathrm{R} 1: \mathrm{K} 1$. The value used for $\mathrm{K} 1$ is the smallest (i.e., the highest affinity) estimate consistent with the data, so the value for $\mathrm{R} 1$ is a lower limit. As was the case with data from $Q-F 18$ cells, values for $R 3$ and $K 2$ were assumed, based on results from rapid applications of $\mathrm{ACh}$ to excised patches (D. J. Maconochie and J. H. Steinbach, unpublished observations). K2 was assumed to be $500 \mu \mathrm{M}$ and R 3 to be 40 .

In sum, P1 and P3 were set to 0. Values for K1 (a minimal value) and $\mathrm{R} 1$ (a minimal value) were set from the data in Figure $6 A$, and values for $\mathrm{K} 2$ and $\mathrm{R} 3$ were assumed. The values used, were $\mathrm{K} 1=5 \mu \mathrm{M}, \mathrm{K} 2=500 \mu \mathrm{M}, \mathrm{L} 1=60 \mathrm{nM}, \mathrm{L} 2=1031 \mathrm{nM}$, $\mathrm{R} 1=7.5 \times 10^{-3}, \mathrm{R} 3=40, \mathrm{P} 1=0$, and $\mathrm{P} 3=0$. These values produced reasonable descriptions of the ability of ACh to elicit responses (Fig. $6 A$ ) and the ability of dTC, to block responses to ACh (Figs. $3 A, 7 A$ ).

One interesting observation is that there are two independent indications that the fetal-type receptor has a higher affinity value for K1 than does the adult-type AChR. One is the greater curvalure of the dose-response relationship at $1 \mu \mathrm{M} \mathrm{ACh} \mathrm{(Fig.} \mathrm{6).}$ The second is that dTC is less effective at blocking responses to $1000 \mathrm{~nm}$ ACh from Q-F1 8 cells than Q-A33 cells (compare Fig. $3 A, B$ ). When fit with the Hill equation, the $K_{h}$ values are $143 \pm 19 \mathrm{nM}$ for fetal receptors and $56 \pm 10 \mathrm{nM}$ for adult receptors (the error estimates are $90 \%$ confidence intervals for the fit value). This difference is predicted by scheme 1 , as shown by the fits in Figure 3, and the shift reflects greater binding competition between $\mathrm{ACh}$ and dTC for the fetal-type receptors.

\section{Discussion}

These results indicate that dTC binds to the fetal and adult types of muscle nicotinic receptor with indistinguishable affinities. However, the ability of dTC to block ACh-elicited responses differs. The results are consistent with the hypothesis that the difference arises because dTC can serve as a weak agonist at fetal AChR, and that the channels of fetal receptors with one $\mathrm{ACh}$ and one $\mathrm{dTC}$ molecule bound have a measurable probability of being open.

A central point in this hypothesis is that the interaction between ACh and dTC takes place by the occupation of the two sites on a single $A C h R$, rather that, for example, reflecting the existence of multiple types of AChR. This conclusion is supported by two observations. First, dTC reduces the slope of the low ACh concentration dose-response curve for fetal receptors (Kopta and Steinbach, 1994; Fig. 6B). Hence, binding of dTC alters the number of bound $\mathrm{ACh}$ molecules needed for $\mathrm{AChR}$ activation. Second, the dose-effect curve for $\mathrm{dTC}$ in the presence of $40 \mathrm{~nm}$ or $100 \mathrm{~nm}$ ACh shows a characteristic humped shape (Fig. $3 B$ ). The dose-effect curve for dTC alone does not show this shape, suggesting that the decrease at higher [dTC] results from the occupation by dTC of both sites on one AChR. The shape is also the strongest qualitative evidence that the affinities measured in the binding assay (Fig. 4) are relevant to activation of fetal AChR by dTC, as the enhancement and eventual block develop at appropriate concentrations of dTC.

We have also performed some additional analysis to relate the binding of dTC to the functional consequences of the binding. The affinities for dTC measured in binding experiments are consistent with the observed dose-effect relationships for fetal and adult cells, when reasonable values for other parameters are used.

\section{Correlation of binding and functional consequences}

The activation scheme used (scheme 1, Fig. 9) is complicated, but is the minimal scheme necessary to account for the data. There are many versions of scheme 1 that are more complex and that would likely describe the data more accurately (e.g., the opening ratios for CRA and $\mathrm{ARC}$ forms might differ), and additional states might also improve the description (e.g., activation of fetal AChR with a single dTC molecule bound).

Several assumptions were made in scheme 1 (Fig. 9). Two center on the description of binding. The available data strongly support the idea that the appearance of two affinities for dTC binding reflect the existence of sites with different affinity, rather than allusteric modulation of affinity (Sine and Taylor, 1981). Further, photolabeling of AChR indicates that the dTC-binding sites include regions of the $\gamma$ and $\delta$ subunits, as well as $\alpha$ (Pederson and Cohen, 1990; Chiara and Cohen, 1992), and expression of cloned subunits has shown that the $\alpha-\gamma$ pair produces a high-affinity site, whereas the $\alpha-\delta$ pair produces a low-affinity site (Blount and Merlie, 1989; Sine and Claudio, 1991). Several studies of AChR activation have concluded that ACh also has two sites of different affinities on the AChR (Jackson, 1988; Sine 
et al., 1990; D. J. Maconochie, unpublished observations). Biochemical studies have not clearly resolved $\mathrm{ACh}$ binding to sites on the nondesensitized AChR (but see Blount and Merlie, 1989) so the lack of allosteric modulation is assumed by analogy. It is also assumed that binding of ACh is not altered by binding of dTC to the other site on the AChR. A second question is whether the site that binds dTC with high affinity binds ACh with high or low affinity. As shown in Figure 9, the predictions were generated assuming that the high-affinity site for dTC is also the high-affinity site for ACh. The converse assumption (Blount and Merlie, 1989) generated slightly lower-quality (by eye) descriptions of the data for Q-F18 cells, using a value of 0.026 for $P 1$ (all other values remained the same), and slightly better descriptions of the data from Q-A33 cells (all values remained the same). Some other assumptions were made purely for simplicity: the opening ratio $(\mathrm{P} 1)$ was made identical for both forms of the heteroliganded $\mathrm{AChR}$, and no activation of AChR was allowed after binding of a single dTC.

As shown in Figures 3, 5, and 6, this scheme can produce a reasonable description of all of the data. However, there are some features of the data that do not agree with this simple analysis. The predicted curves in Figure $3 B$ do not exactly match the data, particularly that for current elicited by $40 \mathrm{~nm} A C h$, and the concentration dependence for activation by dTC is flatter than predicted (Fig. 5). These differences might be the result of some inaccuracy in the values for ACh binding or activation, or the activation of $\mathrm{AChR}$ with one bound $\mathrm{dTC}$ molecule.

\section{The role of desensitization}

The effects of dTC do not appear to involve desensitization. There was no obvious decrement in current during responses to high concentrations of dTC alone (Fig. 5), and it is difficult to explain the dose-effect curves in Figure $3 B$ on the basis of desensitization. Binding studies using intact cells have also indicated that dTC does not appear to desensitize fetal AChR, since there is no time dependence in the ability of dTC to reduce the binding of I-BTX (Sine and Taylor, 1979).

The data on activation and block by dTC indicate that dTC binding occurs at the ACh-binding site. The observation that dTC produces little desensitization even at high site occupancy is consistent with two possibilities. The doubly liganded but closed state of the receptor may desensitize much more slowly than the open state for all agonists, or the rate of desensitization may be sensitive to the nature of the agonist.

\section{Studies of other partial agonists}

The aclions of succinyldicholine and decamethonium as partial agonists also have been examined (Adams and Sakmann, 1978; Marshall et al., 1990, 1991; Liu and Dilger, 1993). Analysis of currents through single open channels at frog neuromuscular junctions activated by succinyldicholine indicated that its doseeffect relationship could be explained by a lower open ratio than ACh, combined with a greater ability to block channels (Marshall et al., 1990). The ratio of the opening to closing rates for AChR with two bound succinylcholine molecules (P3) was estimated to be about 4.8, compared to 40 for $\mathrm{ACh}$ (Colquhoun and Sakmann, 1985). The main factor was an estimated 10-fold lower opening rate, with little change in closing rate. Liu and Dilger (1993) performed experiments similar to those presented here using rapid applications of mixtures of $\mathrm{ACh}$ and decamethonium to mammalian fetal receptors. They concluded that decamethonium is a true partial agonist, with a opening ratio for the diliganded form (P3) of about 0.016 compared to 20 for ACh (a relative efficacy of $8 \times 10^{-4}$ ). Again, the main factor was a large decrease in the channel opening rate. The heteroliganded form $(\mathrm{Pl})$ had an opening ratio of about $2.5(0.125$ times that for ACh diliganded AChR). Decamethonium, therefore, is about 200-fold more efficacious than dTC as an agonist at fetal-type receptors. None of these studies, however, have obtained independent data on the binding of the partial agonists to the receptors.

\section{Comparison to previous findings}

Sine and Taylor (1981) found that curariform antagonists blocked both the binding of iodinated $\alpha$-cobrotoxin and the ${ }^{22} \mathrm{Na}^{+}$uptake elicited by $30 \mu \mathrm{M}$ carbamylcholine when the fetal-type AChR expressed by clonal $\mathrm{BC} 3 \mathrm{H}-1$ cells were studied. In general, the functional block was well described by the affinities derived from studies of toxin binding, although a slight tendency was observed to lower amounts of block than predicted. However, a higher agonist concentration was used by Sine and Taylor (1981), and dTC itself was not examined in their experiments. Hence, the enhancement of response that we have observed at low concentrations of ACh and dTC might not have been as manifest under the conditions they used.

Our observations resolve apparent contradictions between previous studies of dTC binding, which found no difference between fetal and adult AChR, and of functional block by dTC, which found that fetal AChR are blocked less effectively. It is likely that the concentrations of ACh applied to denervated muscle fibers were relatively low, and so the partial agonist action of dTC at fetal AChR was apparent. Our data suggest, however, that dTC should be approximately equieffective at blocking neuromuscular transmission regardless of whether the postsynaptic receptors are of fetal or adult type. The cleft concentrations of $\mathrm{ACh}$ are so high during transmission (probably $>100 \mu \mathrm{M}$ ) that any partial agonist action of dTC would be negligible.

In sum, we have measured affinities for $\mathrm{dTC}$ and the functional consequences of dTC binding. The data resolve some previously discordant observations. They also demonstrate that the binding steps hypothesized to occur in the functional effects of dTC can be directly measured in a biochemical binding assay. The occupancy predicted from the binding parameters is consistent with the ability of dTC to act as a competitive antagonist for adult AChR and as a partial agonist for fetal AChR, using a standard scheme for receptor activation.

\section{References}

Adams PR, Sakmann B (1978) Decamethonium both opens and blocks end plate channels. Proc Natl Acad Sci USA 75:2994-2998.

Barker CR, Worman CP, Smith JL (1975) Purification and quantification of $\mathrm{T}$ and $\mathrm{B}$ lymphocytes by an affinity method. Immunology 29:765-777.

Beranek R, Vyskocil F (1967) The action of tubocurarine and atropine on the normal and denervated rat diaphragm. J Physiol (Lond) 188: 53-66.

Blount P, Merlie JP (1989) Molecular basis of the two nonequivalent ligand binding sites of the muscle nicotinic acetylcholine receptor. Neuron 3:349-357.

Brockes JP, Hall ZW (1975) Acetylcholine receptors in normal and denervated rat diaphragm muscle. II. Comparison of junctional and extrajunctional receptors. Biochemistry 14:2100-2106.

Chiara DC, Cohen JB (1992) Identification of amino acids contributing to high and low affinity $d$-tubocurarine (dTC) sites on the Torpedo nicotinic acetylcholine receptor (nAChR) subunits. Biophys $\mathrm{J}$ 61:A106. 
Colquhoun D, Rang HP (1976) Effects of inhibitors on the binding of iodinated $\alpha$-bungarotoxin to acetylcholine-receptors in rat muscle. Mol Pharmacol 12:519-535.

Colquhoun D, Sakmann B (1985) Fast events in single-channel currents activated by acetylcholine and its analogues at the frog muscle end-plate. J Physiol (Lond) 369:501-557.

Colquhoun D, Sheridan RE (1982) The effect of tubocurarine competition on the kinetics of agonist action on the nicotinic receptor. $\mathrm{Br}$ J Pharmacol 75:77-86.

Colquhoun D, Dreyer F, Sheridan RE (1979) The actions of tubocurarine at the frog neuromuscular junction. J Physiol (Lond) 293: 247-284.

del Castillo J, Katz B (1957) A study of curare action with an electrical micro-method. Proc R Soc Lond [Biol] 146:339-356.

Gu Y, Franco A, Gardner PD, Lansman JB, Hall JR (1990) Properties of embryonic and adult muscle acetylcholine receptors transiently expressed COS cells. Neuron 5:147-157.

Hamill OP, Marty A, Neher E, Sakmann B, Sigworth FJ (1981) Improved patch-clamp techniques for high-resolution current recording from cells and cell-free membrane patches. Pfluegers Arch 391:85100.

Harlow E, Lane D (1988) Antibodies: a laboratory manual. Cold Spring Harbor, New York: Cold Spring Harbor Laboratory.

Jackson MB (1988) Dependence of acetylcholine receptor channel kinetics on agonist concentration in cultured mouse muscle fibres. $\mathrm{J}$ Physiol (Lond) 397:555-583.

Jenkinson DH (1960) The antagonism between tubocurarine and substances which depolarize the motor end-plate. J Physiol (Lond) 152: 309-324.

Kemp G, Morley B, Dwyer D, Bradley RJ (1980) Purification and characterization of nicotinic acetylcholine receptors from muscle. Membr Biochem 3:229-257.

Konnerth A, Lux HD, Morad M (1987) Proton-induced transformation of calcium channel in chick dorsal root ganglion cells. J Physiol (Lond) 386:603-633.

Kopta C, Steinbach JH (1994) Comparison of mammalian adult and fetal nicotinic acetylcholine receptors stably expressed in fibroblasts. J Neurosci 12:3922-3933.

Le Dain AC, Madsen BW, Edeson RO (1991) Kinetics of (+)-tubocurarine blockade at the neuromuscular junction. Br J Pharmacol 103:1607-1613.

Lingle CJ, Steinbach JH (1988) Neuromuscular blocking agents. Int Anesthesiol Clin 26:288-301.

Liu Y, Dilger JP (1993) Decamethonium is a partial agonist at the nicotinic acetylcholine receptor. Synapse 13:57-62.

Maconochie DJ, Knight DE (1989) A method for making solution changes in the sub-millisecond range at the tip of a patch pipette. Pfluegers Arch 414:589-596.

Marshall CG, Ogden DC, Colquhoun D (1990) The actions of suxamethonium (succinyldicholine) as an agonist and channel blocker at the nicotinic receptor of frog muscle. J Physiol (Lond) 428:155-174.

Marshall CG, Ogden D, Colquhoun D (1991) Activation of ion channels in the frog endplate by several analogues of acetylcholine. $J$ Physiol (Lond) 433:73-93.
Mishina M, Takai T, Imoto K, Noda M, Takahashi T, Numa S, Methfessel C, Sakmann B (1986) Molecular distinction between fetal and adult forms of muscle acetylcholine receptor. Nature 321:406-410.

Neubig RR, Cohen JB (1979) Fquilibrium binding of $\left[{ }^{3} \mathrm{H}\right]$ tubocurarine and $\left[{ }^{3} \mathrm{H}\right]$ acetylcholine by Torpedo postsynaptic membranes: stoichiometry and ligand interactions. Biochemistry 24:5464-5475.

Pedersen SE, Cohen JB (1990) $d$-Tubocurarine binding sites are located at $\alpha-\gamma$ and $\alpha-\delta$ subunit interfaces of the nicotinic acetylcholine receptor. Proc Natl Acad Sci USA 87:2785-2789.

Phillips WD, Kopta C, Blount P, Gardner PD, Steinbach JH, Merlie JP (1991) Acetylcholine receptor-rich membrane domains organized in fibroblasts by recombinant $43-\mathrm{kD}$ protein. Science 251 :568570.

Roper JF, Bradley RJ, Dilger JP (1993) Kinetics of the inhibition of ACh receptor channels by $d$-tubocurarine. Biophys J 64:A323.

Sheridan RE, Lester HA (1977) Rates and equilibria at the acetylcholine receptor of Electrophorus electroplaques. J Gen Physiol 70: 187-219.

Sigworth FJ, Sine S (1987) Data transformations for improved display and fitting of single-channel dwell time histograms. Biophys $\mathrm{J} 52$ : $1047-1054$.

Sine SM, Claudio T (1991) $\gamma$ - and $\delta$-subunits regulate the affinity and the cooperativity of ligand binding to the acetylcholine receptor. J Biol Chem 266:19369-19377.

Sine SM, Taylor P (1979) Functional consequences of agonist-mediated state transitions in the cholinergic receptor. J Biol Chem 254: $3315-3325$.

Sine SM, Taylor P (1981) Relationship between reversible antagonist occupancy and the functional capacity of the acetylcholine receptor. J Biol Chem 256:6692-6699.

Sine SM, Claudio T, Sigworth FJ (1990) Activation of Torpedo acetylcholine receptors expressed in mouse fibroblasts. J Gen Physiol 96: 395-437.

Strecker GJ, Jackson MB (1989) Curare binding and the curare-induced subconductance state of the acetylcholine receptor channel. Biophys J 56:795-806.

Takeda K, Trautmann A (1984) A patch-clamp study of the partial agonist actions of tubocurarine on rat myotubes. J Physiol (Lond) 349:353-374.

Thomas KB (1963) Curare. Philadelphia: Lippincott.

Trautmann A (1983) Tubocurarine, a partial agonist for cholinergic receptors. J Neural Trans 18:353-361.

Trautmann A, Feltz A (1980) Open time of channels activated by binding of two distinct agonists. Nature 286:291-293.

Tzartos SJ, Rand DE, Einarson BL, Lindstrom JM (1981) Mapping of surface structures of Electrophorus acetylcholine receptor using monoclonal antibodies. J Biol Chem 256:8635-8645.

Vogel Z, Sytkowski AJ, Nirenberg MW (1972) Acetylcholine receptors of muscle grown in vitro. Proc Natl Acad Sci USA 69:3180-3184.

Ziskind L, Dennis J (1978) Depolarising effect of curare on embryonic rat muscles. Nature 276:622-623. 